\title{
MITOCHONDRIAL DNA 4977 bp DELETION IN CHRONIC CERVICITIS AND CERVIX CANCERS
}

\author{
Kara $\mathrm{M}^{1, *}$ Tatar $\mathrm{A}^{2}$, Borekci B ${ }^{3}$, Dagli F ${ }^{4}$, Oztas $\mathrm{S}^{5}$
}

\begin{abstract}
*Corresponding Author: Murat Kara M.D., Department of Genetics, School of Medicine, Firat University, Universite cad. No. 2, 23119 Elazig, Turkey; Tel: +90-424-233-35-55/1938; Fax: +90-424-238-80-96; E-mail: drmuratkara@hotmail.com
\end{abstract}

\section{ABSTRACT}

Mitochondrial DNA (mtDNA) mutations have been implied in many diseases including cancer and inflammatory diseases. The aim of this study is to investigate the relationship between the 4977 bp deletion of the mtDNA and chronic cervicitis or cervix cancer in patients. The study included a group of patients with chronic cervicitis or cervix cancer, and a control group consisting of individuals without any cervical tissue disease. A total of 72 subjects in an East Turkish population were included in the study. Of these, 35 had chronic cervicitis, 21 had cervix cancer and 16 served as the control group. Isolation of mtDNA was performed from the tissues of these patients and then mtDNA deletions were studied using polymerase chain reaction (PCR). In the cancer groups, there were 9.5\% heteroplasmic and homoplasmic deletions. There were no homoplasmic deletions in the cervicitis and control groups, but the frequencies of heteroplasmic deletions were 80.0 and $31.2 \%$, respectively. Chronic inflammation leading to increased reactive oxygen species (ROS) may be

Department of Medical Genetics, School of Medicine, Firat University, Elazig Turkey

2 Department of Medical Genetics, School of Medicine, Ataturk University, Erzurum, Turkey

Department of Obstetrics and Gynecology, School of Medicine, Ataturk University, Erzurum, Turkey

4 Department of Pathology, School of Medicine, Inonu University, Elazig, Turkey

5 Department of Medical Genetics, School of Medicine, Süleyman Demirel University, Isparta Turkey the cause of the high mtDNA 4977 bp deletion frequencies in cancer and cervicitis. The older age of the cancer patient may suggest that ageing in addition to long time exposure to ROS may lead to deletions and subsequently cancer. This is the first study to investigate the relationship of the mtDNA $4977 \mathrm{bp}$ deletion to chronic cervicitis and cervix cancer.

Keywords: Mitochondrial DNA (mtDNA) mutations, Chronic cervicitis, Cervical cancer.

\section{INTRODUCTION}

Cervical cancer is still a frequent cancer found in women in all over the world and is a prominent cause of cancer-related deaths [1,2]. However, it is a preventable cancer [3]. Chronic cervicitis is the most common gynecological disease and occurs during the reproductive period of life in $50.0 \%$ of women. Although it is often seen, there are important problems in diagnosis, detection of etiologic agents and in treatment [4].

Although multiple genetic events have been identified in the nuclear genome of cervical cancer cells, little is known about genetic changes occurring in the mitochondrial genome during cervical carcinogenesis. Human mitochondrial DNA (mtDNA) is a double-stranded, closed circular structured DNA molecule which is 16,569 bp long $[5,6]$. Mitochondrial DNA contains 37 genes that play a fundamental role in protein synthesis of mitochondrion. Of these, 22 are transfer RNA (tRNA) genes, two are ribosomal RNA (rRNA) genes (12S and 
$16 \mathrm{~S})$ and 13 are mRNA genes that are used in oxidative phosphorylation and respiratory chain $[7,8]$. Besides the gene-coding region, there is a $1124 \mathrm{bp}$ region that is named displacement-loop (D-loop) [9]. This region contains basic sequences required for initiation of mtDNA replication and transcription $[10,1]$. Gene organization and structure of $\mathrm{mtD}$ NA are mostly conserved [11].

The mtDNA gene mutations are found in solid tumors such as bladder, breast, colon, stomach, liver, kidney, lung, pancreas, prostate, esophagus, thyroid, brain, head and neck cancers, and hematological cancers such as acute and chronic leukemia, myelodysplastic syndrome and lymphomas $[10,12]$. In general, gene point mutations, gene deletions and mitochondrial microsatellite instability leading to mitochondrial diseases are expressed in human neoplasms. However, the frequency of these events in different tissues may vary [13-16]. The relationship of mtDNA mutations and cancer is very striking. For instance, in 1998, Polyak et al. [15] reported that $70.0 \%$ of colorectal cancers have somatic mtDNA mutations. The mtDNA 4977 bp deletion is the single most common deletion of mtDNA that is demonstrated in many different types of human tumors including thyroid tumors, hepatocellular carcinoma, esophagus carcinoma and stomach cancer $[14,17]$.

\section{MATERIAL AND METHODS}

Samples and DNA Isolation. This study was conducted during the years 2008-2009 at Ataturk University Faculty of Medicine, Department of Medical Genetics, Department of Pathology, Department of Obstetrics and Gynecology, Erzurum, Turkey, and Firat University Faculty of Medicine Department of Pathology, Elazig, Turkey. The study included 72 participants in an East Turkish population; 35 patients with chronic cervicitis, 21 patients with cervical cancer, and 16 samples taken from formalin-fixed, paraffin-embedded normal cervix tissues (FFPTs). Ethical approval was obtained by the Ataturk University Ethics Committee for the collection and analysis of the samples. The mean ages of the patients with chronic cervicitis was $50.2 \pm$ 8.9 (40-72 years), of the patients with cervix cancer it was $62.4 \pm 9.9$ ( $47-79$ years) and of the samples from the control group it was $45.5 \pm 8.6$ (28-61 years).

Primers, DNA Extraction and Polymerase Chain Reaction Amplification. In order to demonstrate the $4977 \mathrm{bp}$ deletion of mtDNA, the preparation of primers based on gene sequences was obtained from the database website http://www. mitomap.org/. Nucleotide sequences of purchased primers (Bio Basics Inc., Markham, ON, Canada) are shown in the Table 1 . These primer pairs contained two control regions as negative and positive controls and one deletion region. DNA extraction was performed on $5 \mathrm{mg}$ fresh tissue samples of individuals diagnosed as having chronic cervicitis and cervical malignancy by using the DNA isolation kit (GENTRA-Genomic DNA Purification Kit; Madison, WI, USA). For the control group, samples taken from FFPTs were used for DNA extraction by using the DNA isolation kit (DZDNA-Paraffin Embedded Tissue DNA Isolation Kit, Dr. Zeydanli, Ankara, Turkey).

The PCR reactions $(50 \mu \mathrm{L})$ were performed in $10 \mu \mathrm{M}$ Tris- $\mathrm{HCl}, \mathrm{pH} 8.4,50 \mu \mathrm{M} \mathrm{KCl}, 2 \mu \mathrm{M} \mathrm{MgCl} 2$, $200 \mu \mathrm{M}$ each of dNTP, 20 pmol of each primer and 5 U Taq polymerase (Fermentas Inc., Hanover, MD, USA) in a thermocycler under the following conditions: $95^{\circ} \mathrm{C}$ for $1 \mathrm{~min}$. (initial denaturation) followed by 31 cycles at $94^{\circ} \mathrm{C}$ for 25 seconds (denaturation), $60^{\circ} \mathrm{C}$ for 35 seconds (annealing), $72^{\circ} \mathrm{C}$ for $1 \mathrm{~min}$. (extension), and a final extension at $72^{\circ} \mathrm{C}$ for $10 \mathrm{~min}$. An aliquot $(10 \mu \mathrm{L})$ of each amplicon was examined

Table 1. The polymerase chain reaction primers used in this study.

\begin{tabular}{|c|c|l|}
\hline Primer & PCR Product Size (bp) & \multicolumn{1}{|c|}{ Sequences of Primer Pairs (5’>3’) } \\
\hline Deletion region & $470(8164-13611)$ & $\begin{array}{l}\text { Forward: CGG TCA ATG CTC TGA AAT CTG TG } \\
\text { Reverse: TCG AGT GCT ATA GGC GCT TGT C }\end{array}$ \\
\hline Positive control & $1029(6251-7280)$ & $\begin{array}{l}\text { Forward: TAT AGT GGA GGC CGG AGC AG } \\
\text { Reverse: GAA TGA GCC TAC AGA TGA TA }\end{array}$ \\
\hline Negative control & $564(9981-10545)$ & $\begin{array}{l}\text { Forward: TGA GGG TCT TAC TCT TTT AGT } \\
\text { Reverse: GGT GTG AGC GAT ATA CTA GT }\end{array}$ \\
\hline
\end{tabular}


on $1.8 \%$ agarose gels and stained with ethidium bromide. During visualization, a $470 \mathrm{bp}$ fragment for the deletion region, a 1029 bp fragment for the positive control site outside the deletion region and a 564 bp fragment for the negative control site in the deletion region were observed.

Statistical Analyses. All statistical analyses were performed by using the SPSS for Windows computing program version 12.0. Disease type and mtDNA results were tested by chi-square. A $p$ value lower than 0.05 was accepted as statistically significant.

\section{RESULTS}

In this study we investigated mtDNA deletions by isolating mtDNA of tissues from individuals with chronic cervicitis and cervix cancer as the study group and from individuals without any cervical disease as the control group. In the assessment of mtDNA obtained from material of 35 patients with chronic cervicitis, we found heteroplasmy in 28 patients $(80.0 \%)(p=0.0001)$. Seven patients $(20.0 \%)$ were normal, whereas none of the patients with chronic cervicitis had the 4977 bp homoplasmic deletion. The mtDNA assessment of 21 patients with cervical cancer showed that 17 patients $(81.0 \%)$ were normal, two patients $(9.5 \%)$ had heteroplasmy, and two patients (9.5\%) had the 4977 bp homoplasmic deletion $(p=0.0001)$. Study of the mtDNA tissue samples from 16 patients in the control group showed that five patients had heteroplasmy $(31.2 \%), 11$ individuals were normal $(68.8 \%)(p$ $=0.0001)$. None of the control subjects had a 4977 bp homoplasmic deletion (Table 2 and Figure 1).

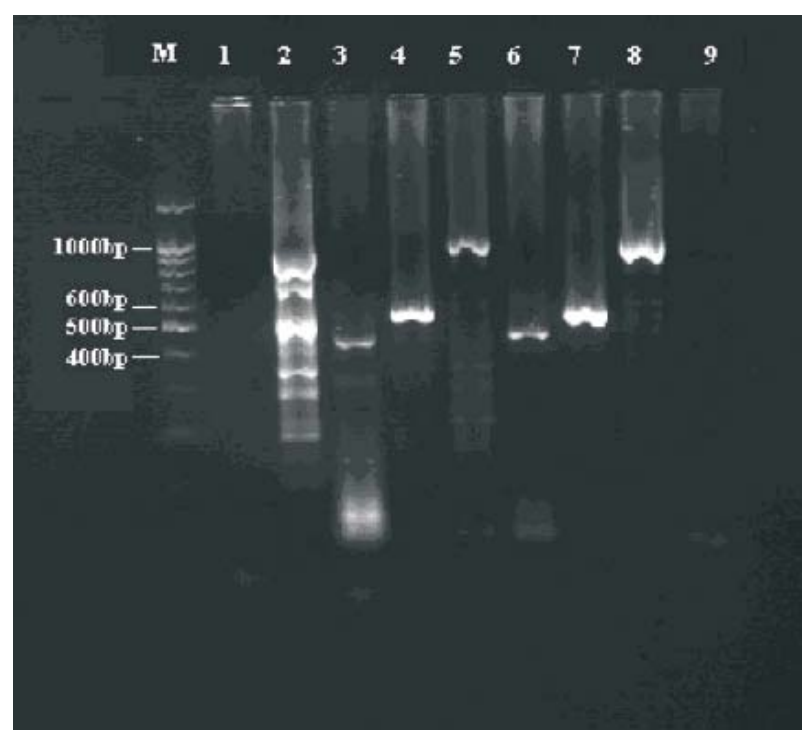

Figure 1. Agarose gel electrophoresis of PCR products obtained from mitochondrial DNA. Lane M, $100 \mathrm{bp}$ Plus DNA Ladder (Fermentas); Sample 1 shows a homoplasmic deletion; sample 2 shows a heteroplasmic deletion; sample 3 did not show the mutation.

\section{DISCUSSION}

Mutations in mitochondrial protein genes are the reason of not only neurodegenerative diseases but also ophthalmological and hematological diseases [12]. Studies demonstrating the relationship of mtDNA mutations with cancer and infections were conducted in many different patient groups $[10,18]$. Accumulation of mtDNA mutations is directly related to ageing and the development of degenerative diseases. It has been shown that the 4977 bp deletion accumulated in tissues such as brain, skeletal and cardiac muscle increases with age [19]. In this study, we demonstrated the relationship of $4977 \mathrm{bp}$

Table 2. The mitochondrial DNA 4977 bp deletion in the groups.

\begin{tabular}{|c|c|c|c|c|c|}
\hline & $\boldsymbol{n}$ & Normal & Heteroplasmy & Homoplasmy & $\boldsymbol{p}$ Value $^{\mathrm{a}}$ \\
\hline Cervix cancers, $\boldsymbol{n}(\mathbf{\%})$ & 21 & $17(81.0)$ & $2(9.5)$ & $2(9.5)$ & 0.0001 \\
\hline Chronic cervicitis, $\boldsymbol{n}(\%)$ & 36 & $7(20.0)$ & $28(80.0)$ & $0(0.0)$ & 0.0001 \\
\hline Control group, $\boldsymbol{n}(\mathbf{\% )}$ & 16 & $11(68.8)$ & $5(31.2)$ & $0(0.0)$ & 0.0001 \\
\hline Total, $\boldsymbol{n}(\%)$ & 72 & $36(50.0)$ & $34(47.2)$ & $2(2.8)$ & \\
\hline
\end{tabular}

${ }^{\text {a }} p$ Values of the chi-square test. 
mtDNA deletions with chronic cervicitis and cervix cancer.

Liu et al. [20] determined 60.0\% mtDNA mutations in malignant ovarian tissues. The rate of $\mathrm{mtD}$ NA mutations were 68.8 and $25.0 \%$, respectively, for malignant tumors and benign tumors. Wu et al. [17] in their study on 31 gastric cancer patients, found the $4977 \mathrm{bp}$ deletion in normal gastric tissues in $17(55.0 \%)$ of 31 patients. They also found that only three $(10.0 \%)$ of all gastric cancer samples carried mtDNA deletions. These findings suggest that the 4977 bp deletions accumulated in less frequency in gastric cancer tissues [17].

Cervical cancer is the second most common cause of cancer deaths after breast cancer in women and it comprises $10.0 \%$ of all cancer deaths [21]. There are few studies investigating the relationship between mtDNA mutations and cervix cancer $[2,22]$. In our study, 9.5\% heteroplasmic and homoplasmic mtDNA 4977 bp deletions were observed in cervix cancer. In addition, the ages of two patients with mtDNA 4977 bp homoplasmic deletion were 73 and 79 years. These older ages suggest that the age-dependent accumulation of mtDNA deletions is one of the reasons of the frequent homoplasmy in cervical cancer. Secondly, these patients might be exposed to more infections because of their advanced age, and mitochondrial ROS production might be increased. Thus, chronic inflammation via ROS production may lead to mtDNA mutations and accumulation of mutant mtDNA in cell.

The reason for the lack of deletions in other patients might be that cells undergo apoptosis when mitochondrial mutations exceed threshold value [17]. The evidence suggests that the effects of ROS on the pathogenesis of chronic diseases including cancer vary [23]. Although cells have antioxidant systems against ROS-dependent oxidative damage, oxidative damages accumulate during life and this accumulation leads to damage in DNA, proteins and lipids. Therefore, it is suggested that oxidative stress has an important role in the development of age-dependent diseases such as neurodegenerative disorders, arthritis, arteriosclerosis and cancer [24]. A study by Canakci et al. [25] found that 24 (80.0\%) of 30 chronic periodontitis patients had the $4881 \mathrm{bp}$ mtDNA deletion. They suggested that increased ROS production due to infection in chronic periodontitis may be related to $4881 \mathrm{bp}$ mtDNA deletion [25].
In our study, patients with chronic cervicitis had a higher frequent heteroplasmic mtDNA $4977 \mathrm{bp}$ deletions. This finding supports the hypothesis that increased ROS production during chronic inflammation in cervix tissues leads to mtDNA mutations. However, the minimum threshold effect should be exceeded by the emergence of clinical findings and dysfunction in tissues $[6,26]$. This idea may show that mutation rate is important in disease expression and in defining mitochondrial diseases.

This is the first study that uses the mtDNA $4977 \mathrm{bp}$ deletion in understanding of pathogenesis in patients with chronic cervicitis and cervix cancer. Investigating other mtDNA mutations in these patient groups may gain insight for clinical approaches.

Declaration of Interest. The authors report no conflicts of interest. The authors alone are responsible for the content and writing of this article.

\section{REFERENCES}

1. Kalliala I, Nieminen P, Dyba T, Pukkala E, Anttila A. Cancer free survival after CIN treatment: comparisons of treatment methods and histology. Gynecol Oncol. 2007; 105(1): 228-233.

2. Sharma H, Singh A, Sharma C, Jain SK, Singh N. Mutations in the mitochondrial DNA D-loop region are frequent in cervical cancer. Cancer Cell Int. 2005; 5: 34 .

3. Crosbie EJ, Kitchener HC. Human papillomavirus in cervical screening and vaccination. Clin Sci (Lond). 2006; 110(5): 543-552.

4. Lusk MJ, Konecny P. Cervicitis: a review. Curr Opin Infect Dis. 2008; 21(1): 49-55.

5. Gomez-Zaera M, Abril J, Gonzalez L, Aguilo F, Condom E, Nadal M, Nunes V. Identification of somatic and germline mitochondrial DNA sequence variants in prostate cancer patients. Mutat Res. 2006; 595(12): $42-51$.

6. Wei YH, Lee HC. Oxidative stress, mitochondrial DNA mutation, and impairment of antioxidant enzymes in aging. Exp Biol Med. 2002; 227(9): 671682.

7. Anderson S, Bankier AT, Barrell BG, de Bruijn MH, Coulson AR, Drouin J, Eperon IC, Nierlich DP, Roe BA, Sanger F, Schreier PH, Smith AJ, Staden R, Young IG. Sequence and organization of the human mitochondrial genome. Nature. 1981; 290(5806): 457-465.

8. Greaves LC, Taylor RW. Mitochondrial DNA mutations in human disease. IUBMB Life. 2006; 58(3): 143-151. 
9. Suzuki M, Toyooka S, Miyajima K, Iizasa T, Fujisawa T, Bekele NB, Gazdar AF. Alterations in the mitochondrial displacement loop in lung cancers. Clin Cancer Res. 2003; 9(15): 5636-5641.

10. Penta JS, Johnson FM, Wachsman JT, Copeland WC. Mitochondrial DNA in human malignancy. Mutat Res. 2001; 488(2): 119-133.

11. Taanman JW. The mitochondrial genome: structure, transcription, translation and replication. Biochim Biophys Acta. 1999; 1410(2): 103-123.

12. Carew JS, Huang P. Mitochondrial defects in cancer. Mol Cancer. 2002;1-9.

13. Czarnecka AM, Golik P, Bartnik E. Mitochondrial DNA mutations in human neoplasia. J Appl Genet. 2006; 47(1): 67-78.

14. Dai JG, Xiao YB, Min JX, Zhang GQ, Yao K, Zhou RJ. Mitochondrial DNA 4977 BP deletion mutations in lung carcinoma. Indian J Cancer. 2006; 43(1): 20 25.

15. Polyak K, Li Y, Zhu H, Lengauer C, Willson JK, Markowitz SD, Trush M, Kinzler KW, Vogelstein B. Somatic mutations of the mitochondrial genome in human colorectal tumours, Nat Genet. 1998; 20(3): 291-293.

16. Parrella P, Xiao Y, Fliss M, Sanchez-Cespedes M, Mazzarelli P, Rinaldi M, Nicol T, Gabrielson E, Cuomo C, Cohen D, Pandit S, Spencer M, Rabitti C, Fazio VM, Sidransky D. Detection of mitochondrial DNA mutations in primary breast cancer and fine-needle aspirates. Cancer Res. 2001; 61(20): 7623-7626.

17. Wu CW, Yin PH, Hung WY, Li AF, Li SH, Chi CW, Wei YH, Lee HC. Mitochondrial DNA mutations and mitochondrial DNA depletion in gastric cancer. Genes Chromosomes Cancer. 2005; 44(1): 19-28.
18. Birch-Machin MA. The role of mitochondria in ageing and carcinogenesis. Clin Exp Dermatol. 2006; 31(4): 548-552.

19. Mohamed SA, Wesch D, Blumenthal A, Bruse P, Windler K, Ernst M, Kabelitz D, Oehmichen M, Meissner C. Detection of the 4977 bp deletion of mitochondrial DNA in different human blood cells. Exp Gerontol. 2004; 39(2): 181-188.

20. Liu VW, Yang HJ, Wang Y, Tsang PC, Cheung AN, Chiu PM, Ng TY, Wong LC, Nagley P, Ngan HY. High frequency of mitochondrial genome instability in human endometrial carcinomas. $\mathrm{Br} \mathrm{J}$ Cancer. 2003; 89(4): 697-701.

21. Yaren A, Ozkilinc G, Guler A, Oztop I. Awareness of breast and cervical cancer risk factors and screening behaviours among nurses in rural region of Turkey. Eur J Cancer Care. 2008; 17(3): 278-284.

22. Chen D, Zhan H. Study on the mutations in the D-loop region of mitochondrial DNA in cervical carcinoma. $\mathrm{J}$ Cancer Res Clin Oncol. 2009; 135(2): 291-295.

23. Federico A, Morgillo F, Tuccillo C, Ciardiello F, Loguercio C. Chronic inflammation and oxidative stress in human carcinogenesis. Int J Cancer. 2007; 121(11): 2381-2386.

24. Valko M, Rhodes CJ, Moncol J, Izakovic M, Mazur M. Free radicals, metals and antioxidants in oxidative stress-induced cancer. Chem Biol Interact. 2006; 160(1): 1-40.

25. Canakci CF, Tatar A, Canakci V, Cicek Y, Oztas S, Orbak R. New evidence of premature oxidative DNA damage: mitochondrial DNA deletion in gingival tissue of patients with periodontitis. J Periodontol. 2006; 77(11): 1894-1900.

26. Mancuso M, Filosto F, Choub A, Tentorio M, Broglio L, Padovani A, Siciliano G. Mitochondrial DNA-related disorders. Biosci Rep. 2007; 27(1-3): 31-37. 